\title{
The Late Alpine structural development of the Kleszczów Graben (Central Poland) as a result of reactivation of the pre-existing, regional dislocations
}

\author{
R. Gotowała and A. Hałuszczak \\ Institute of Geological Sciences, University of Wrocław, pl. M. Borna 9, 50-204 Wrocław, Poland \\ Received: 5 January 2000 - Revised: 21 May 2001 - Accepted: 30 May 2001
}

\begin{abstract}
The Kleszczów Graben forms the easternmost part of the Tertiary graben system, which occurs on the North European Paleozoic platform, in the foreland of the Polish Carpathians. It is concluded that structural features of the graben, and its development during the TertiaryQuaternary, were strongly influenced by a pre-existing fault pattern within the Paleozoic-Mesozoic basement. Tectonic analysis of the drill hole data revealed the occurrence of two main fault sets reactivated or established during the Kimmeride and Laramide phases. One of the fault sets trends NESW to ENE-WSW, and the second trends NW-SE to WNWESE. Most of the faults were formed as branches of two distinctive dislocations of regional extent: the KluczborkBełchatów Fault (KBF) and the Holy Cross Fault (HCF). Our reconstruction of the Late Alpine evolution of the Kleszczów Graben was based upon two data sets: large number of boreholes, and detailed field investigations in the open-pit brown coal mine "Bełchatów". The Kleszczów Graben developed in three stages. Stage I - The opening of the graben took place in the Late Oligocene-Early Miocene as a result of the reactivation of the WSW-ENE and NW-SE trending, preexisting faults in transtensional regime (the maximum stress axis parallel to WNW-ESE). Subsequently, a succession of pull-apart basins, arranged along the WSW-ENE trend, was formed. This stage ended in the Late Sarmatian-Early Pannonian with a vertical displacement of the Cenozoic series. This was the effect of the movements along the NE-SW trending faults in the extensional regime (maximum stress axis plunging at a high angle). Stage II - The structural rearrangement of the graben occurred during the Late-Middle Pleistocene and was caused by strike-slip movements on the NW-SE reverse faults in transpressional regime (the maximum stress axis along NW-SE). Stage III - The recent reactivation of some dislocations in the Kleszczów Graben area, induced in part by mining works and evidenced by numerous earthquakes, of up to 4.6 in magnitude. Most of these seis-
\end{abstract}

Correspondence to: R. Gotowała (romgot@ing.uni.wroc.pl) mic events are aligned and apparently controlled by particular faults of the Kleszczów-Kodra̧b Fault zone (KKF). The focal mechanism solution suggests a fault displacement characterized by the oblique-slip kinematics.

\section{Introduction}

The Kleszczów Graben forms the easternmost part of the Late Alpine tectonic depressions developed within the foreland plate of the Polish Carpathians (Fig. 1). The graben is located in the southern part of the Polish Lowland, within the boundary zone that occurs between the Łódź Depression to the north and the Radomsko Elevation to the south, in the Szczecin-Łódź-Miechów Synclinorium (Figs. 1, 2). At the present stage of its recognition, the Kleszczów Graben can be defined as a complex, multi-segmented, subsided structure, 2 to $3 \mathrm{~km}$ wide, which extends for a distance of some $80 \mathrm{~km}$ between the rivers of Pilica (east) and Warta (west) (Fig. 2). It has a shape of the southward-open arc, of which the eastern part stretches WNW-ESE (i.e. in the direction of the Holy Cross Fault - HCF), and the western part stretches WSWENE (i.e. in the direction of the regional fault of BrzegKluczbork - BKF) (Gotowała, 1987). Due to these structural relationships, the Kleszczów Graben appears to link the Holy Cross Mountains with the tectonic elements of the Fore-Sudetic Monocline, as already noticed by Baraniecka (1975).

The basement of the 250 to $600 \mathrm{~m}$ thick QuaternaryTertiary sequence is represented by the Jurassic and Cretaceous units, i.e. uppermost members of the PermianMesozoic complex of the Mid-Polish Trough. Permian rocks are present only in a small area of the Dębina Salt Dome (Fig. 2). The Mesozoic strata were folded and faulted during the Laramide phase (Early Paleogene) of the Alpine orogeny. Many parallel, NW-SE trending fold structures were formed (Pożaryski, 1971, 1974). The Kleszczów Graben was origi- 


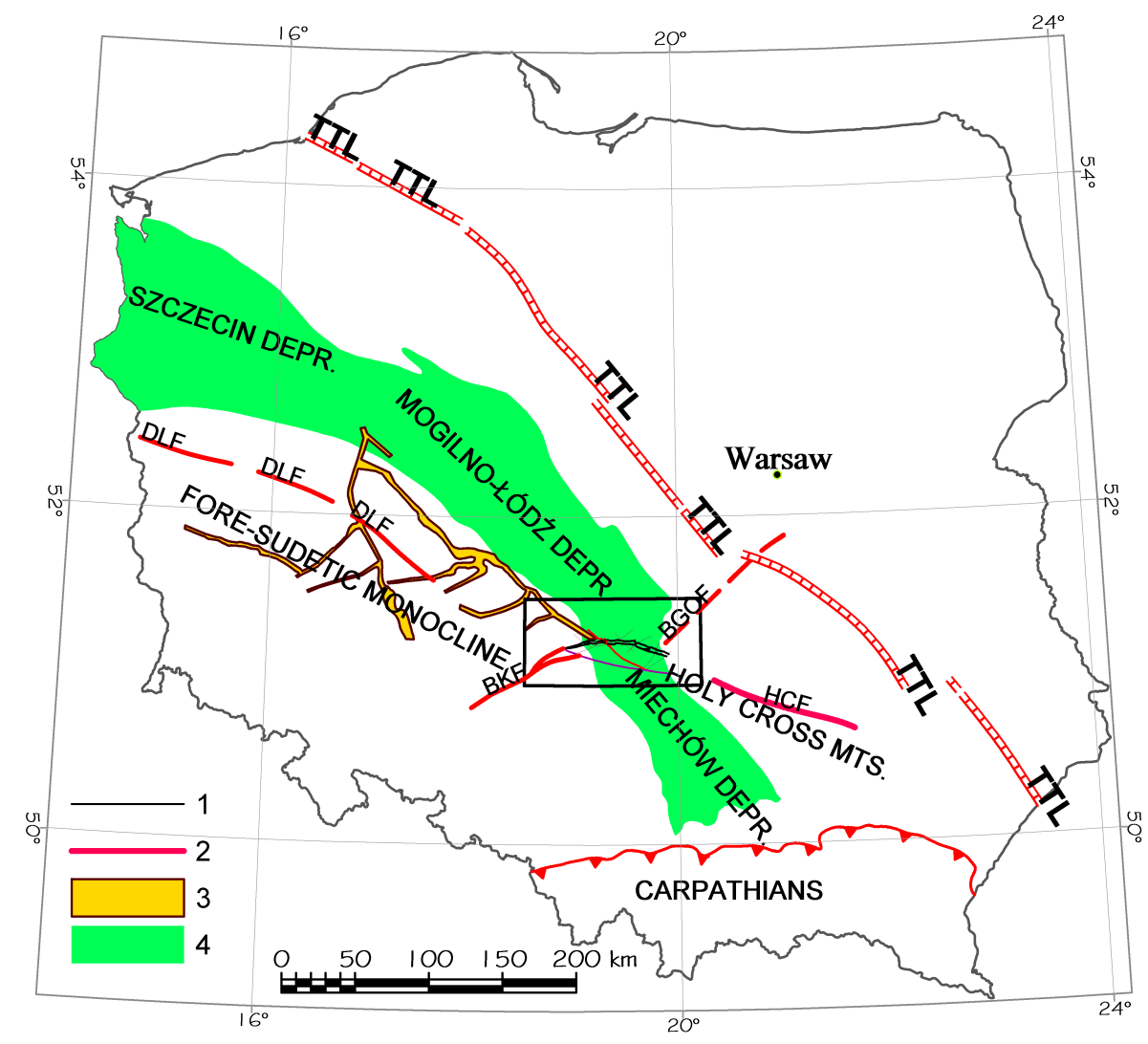

Fig. 1. Area of study and location of the major structural components. Notations are: 1) master faults of the Kleszczów Graben; 2) regional fault zones after Dadlez (1997), Rühle et al. (1978); 3) Tertiary grabens system after gravity data (Dąbrowski, 1980); 4) Szczecin-MogilnoŁódź-Miechów Depression area. Abbreviations are: TTL - Teisseyre-Tornquist Line after Pożaryski (1986); HCF - Holy Cross Fault; DLF - Dolsk Fault; BOGF - Bełchatów-Opoczno-Grójec Fault; BKF - Brzeg-Kluczbork Fault; DEPR - depression.

nated in the Late Alpine phases (Early Miocene), as a result of faulting in the hinge zone between the Łódź Depression and the Radomsko Elevation, which place corresponds to the Variscan relief slope in deeper, subsurface structure.

Geological research has been carried out, since 1977, in the open-pit brown coal mine "Bełchatów", which is located approximately $15 \mathrm{~km}$ south of the town of Bełchatów, in the central part of the Kleszczów Graben (Fig. 3).

The review of the existing literature, and of the geological documentation files, revealed that there are considerable differences between various authors as to the assessment of the geometrical features of the Kleszczów Graben, both on a scale of the entire graben structure as well as of its particular parts. There are also some controversies concerning the origin of the graben, that has been alternatively explained by either strictly tectonic (endogenic) factors (e.g. Baraniecka, 1971, 1982), by salt mobility (halokinesis or halotectonics - e.g. Kossowski, 1974), or by salt dissolution and removal from the basement (subrosion - Wysokiński, Zapaśnik, 1984; Głazek, 1989). In more recent papers, particularly in those based on direct field observations, the dominant role is played by the theory assuming a tectonic origin of the graben, and its relationships to the regional-scale faults initiated during earlier orogenic events (e.g. Bogacz,
Kopka, 1981; Gotowała, 1982, 1987, 1994; Brodzikowski et al., 1987; Krzyszkowski, 1989, 1992).

\section{Data and methods}

An analysis of the subsurface data from the Kleszczów Graben area was completed using borehole results from, in total, 3096 wells. The majority of the wells has been drilled during documentation works on brown coal deposits. The core from those drill holes yielded structural information on the upper levels of the Permian-Mesozoic basement (e.g. tilt of the strata, brecciation, faults and slickensides, tectonic repetitions or omissions, fractures, types of their infilling, stylolites). Some of the boreholes (69) have been drilled as a part of the petroleum exploration program and supplied data from the deeper stratigraphic horizons, from the Lower Carboniferous up to the top of the Mesozoic. The resulting material has enabled a reconstruction of regional faults and the detailed delineation of the Kleszczów Graben.

Mesostructural analysis of the Tertiary-Quaternary deposits that constitute infill of the graben, has been carried out within the "Bełchatów" mine. 


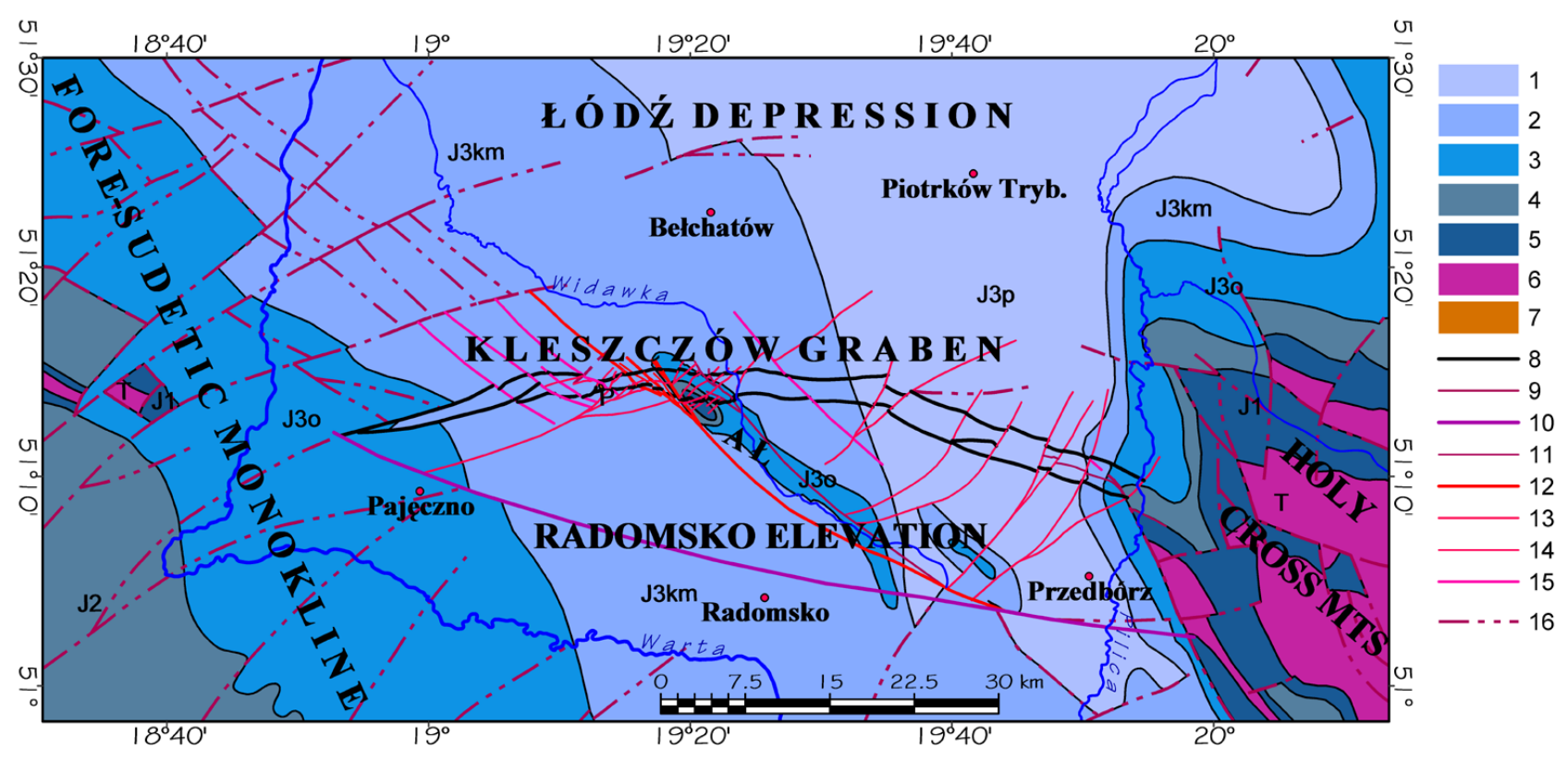

Fig. 2. Geological map of the Kleszczów Graben area without Cenozoic and Cretaceous strata (lithostratygrafic units after Rühle et al. 1978, modified and supplemented). Notations are: 1) Late Jurassic - Portlandian (J3p); 2) Late Jurassic - Kimmeridgian (J3km); 3) Late Jurassic - Oxfordian (J3o); 4) Middle Jurassic (J2); 5) Early Jurassic (J1); 6) Triassic (T); 7) Permian - Zechstein (P); 8)-15) faults of the Kleszczów Graben; 16) faults after Rühle et al. (1978). Abbreviations are: AŁ - Łȩkińsko Anticline.

\section{The main pre-Tertiary dislocations in the Permian- Mesozoic complex}

A borehole analysis of the sediment thicknesses and of the top surface morphologies of selected Permian-Mesozoic lithostratigraphic units (up to Middle Jurassic, inclusive) as well as of the synoptic thickness map of the PermianMesozoic complex (except for the Upper Jurassic and Cretaceous) allowed to recognize the main faults of the studied area (Fig. 3). The faults form two sets, that correspond to dislocations of regional extent: one striking WNW-ESE to NW-SE, and the second striking SW-NE.

\subsection{The WNW-ESE and NW-SE striking fault set}

It is generally accepted that the main dislocation of the Holy Cross Mountains, the HCF, has a deep-seated, west trending continuation that cuts across the Radomsko Elevation (Znosko, 1974; Hakenberg, 1980; Karnkowski, 1980). As suggested by Trzepierczyński (1985, 1987), the HCF merges into the Dolsk Fault (Fore-Sudetic Monocline) in the vicinities of Pajęczno, following a change in the strike from WNWESE to NW-SE. According to the reported subsurface data, in the area of study, the HCF manifests itself mainly as a zone of significant changes in the thickness of the PermianMesozoic complex, and in associated variations of the top Variscan surface. The change in the density and direction of the isopach contours define a line located immediately north of Radomsko and Pajęczno, that may reflect an influence of the buried HCF. Furthermore, this line, or at least some of its segments, is confirmed by the southern extent of the Rotliegend deposits (Fig. 3).

The Kodrąb-Kleszczów Fault (KKF) is the fault zone, most distinctly recorded on all of the analysed thickness distribution and top surface structural maps (from the Permian upwards). It represents, most likely, a splay branching to NW from the HCF master fault. The position of the KKF coincides with the southwestern marginal zone of the early Kimmerian grabens that continue from Przedbórz to Poznań (Pożaryski 1974; Deczkowski, Gajewska 1979).

\subsection{The SW-NE striking fault set}

Another local, but a significant change in the WNW-ESE trend of the Permian isopach lines, deflecting them towards NW-SE, is interpreted to reflect an activity of two transverse faults in the basement: one near to Radomsko, and other along the line Pajęczno-Kleszczów. The faults are referred to as the Radomsko-Sulejów Fault (RSF) and the Pajęczno-Kleszczów Fault (PKF), respectively. Southwest of Pajęczno, the PKF coincides with the limit of the Zechstein strata and may represent a fragment of the regional Brzeg-Kluczbork Fault (BKF) (Trzepierczyński, 1985, 1987) (Figs. 1, 2, 3). A further, NE trending extension of this fault, known as the Bełchatów-Opoczno-Grójec Fault (BOGF), has a considerable importance as a limit of the salt tectonics structures (Marek et al., 1983; Bac-Moszaszwili, Morawska, 1975; Pożaryski 1974; Pożaryski et al., 1980; Pożaryski, Dembowski, 1984). The trend of this fault-line within the Kleszczów Graben is marked by a characteristic deflections of boundaries of the Permian deposits, and by the occur- 


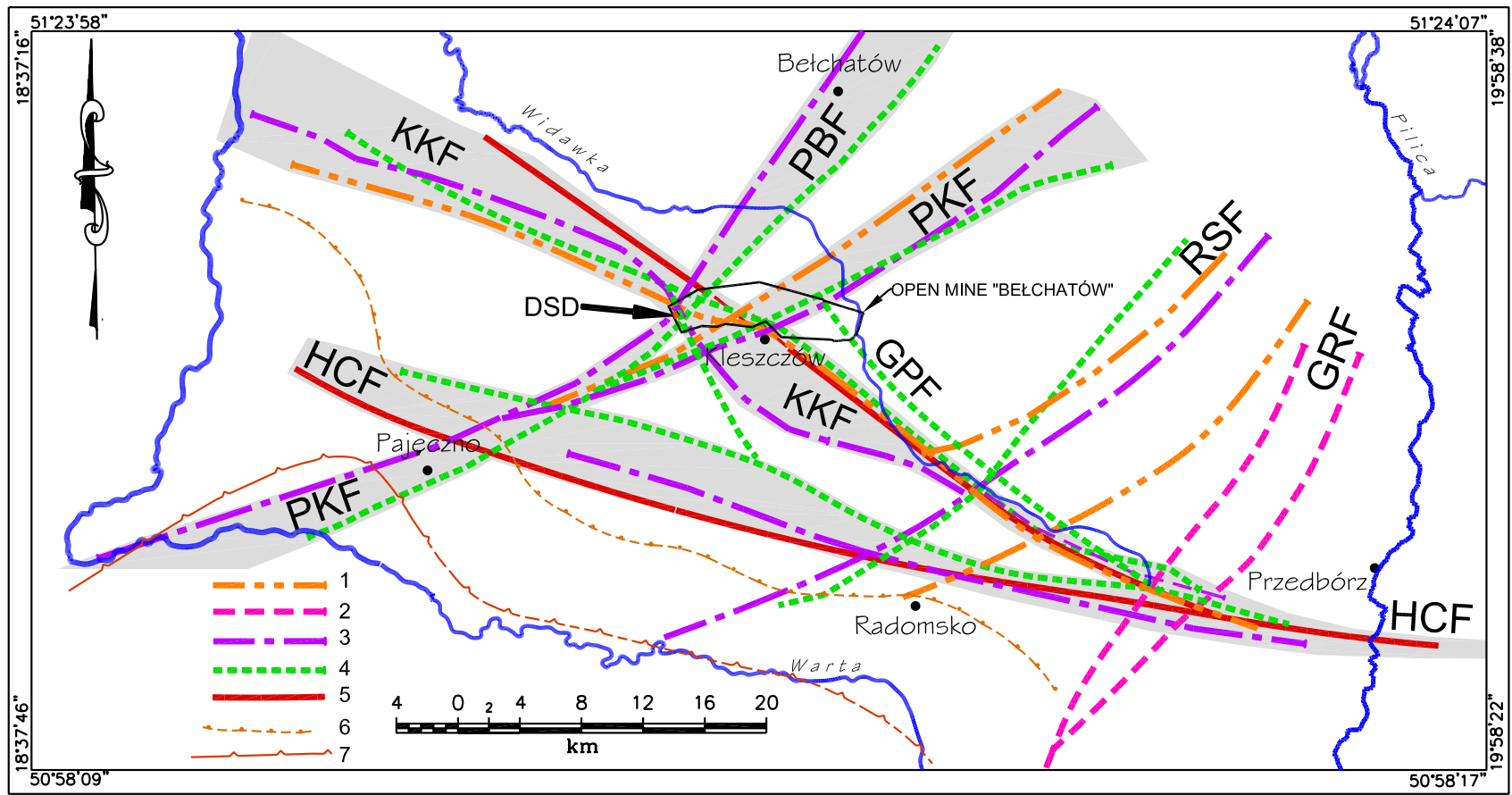

Fig. 3. Main regional faults in the Permian-Mesozoic complex of the Kleszczów Graben area. Based on an analysis of the sediment thickness and the top surface morphology of selected units (up to Middle Jurassic, inclusive). Notations are: 1) best recorded in Permian complex; 2) best recorded in Early Triassic to Late Triassic complex; 3) best recorded in Middle Triassic to Late Triassic complex; 4) best recorded in Late Triassic to Middle Jurassic complex; 5) recorded in most units of the Permian-Mesozoic complex; 6) limit of the Rotliegend deposits; 7) limit of the Zechstein deposits. Abbreviations are: HCF - Holy Cross Fault; KKF - Kodrąb-Kleszczów Fault; GPF - Gomunice-Piaski Fault; PKF - Pajęczno-Kleszczów Fault; PBF - Pajęczno-Bełchatów Fault; RSF - Radomsko-Sulejów Fault; GRF - Gidle-Ręczno Fault; DSD - Dębina Salt Dome.

rence of the Dębina Salt Dome, the present top of which has been detected on a depth of $150 \mathrm{~m}$ (Fig. 4). During the younger stages of tectonic activity (Tertiary and Quaternary), the ascending salt masses utilized the tectonic weakness zone, which was created at the intersection of the PKF with the faults trending NW-SE (Figs. 2, 3).

The differentiation of the Permian-Mesozoic sedimentary infill within the examined part of the Mid-Polish Trough led to the identification of two transverse, NE-SW trending faults, the Radomsko-Sulejów Fault (RSF) and the GidleRęczno Fault (GRF), located to the northeast of the KKF. Their presence is clearly manifested in the thickness distribution of the Permian-Mesozoic complex, but are less distinct in structural images of top surfaces of the particular members . To the NE of the KKF, the RSF and the GRF split to form several narrow grabens and horsts (Fig. 3). Towards the SW, the faults are less apparent, however, it is highly probable that they continue into the Fore-Sudetic Monocline.

Tectonic movements of the Early Kimmerian phase (Triassic) have left a very distinct record of activity of the main faults in the studied region. Displacements, with a significant horizontal component and dextral sense of shear, occurred on the HCF zone and on its splay faults - the KleszczówKodrąb Fault (KKF) and the Gomunice-Piaski Fault (GPF). The thickness distribution of the uppermost Triassic and the
Lower and Middle Jurassic constitutes, as well, a record of the activity of the Kluczbork-Bełchatów Fault (KBF) and two faults that form its prolongation (PKF, PBF). A coordinated activity on these faults has resulted in a mosaiclike distribution of maximum depressions and elevations in the sedimentary basin at that time. This was accompanied by piling up of salt bodies in the southern part of the basin (Łódź Depression), and was recorded, as stratigraphic gaps that included the uppermost Rhaetian and Liassic beds, in a number of the boreholes (Mrozek, 1975; Pożaryski, 1971, 1974).

The Middle Jurassic sequence is the uppermost lithostratigraphic unit, of which the present-day thickness directly reflects on depositional conditions. Associated with faultblock tectonics was a subsequent folding, which culminated during the Laramide phase (Early Paleogene), and was compensated by the erosion of the Cretaceous and Upper Jurassic sequences. Locally, this erosion affected, as well, the Lower Jurassic strata, for example in the hinge of the most prominent fold structure of the Kleszczów Graben area - the Łękińsko Anticline) (Fig. 2).

\section{The Laramide tectonics}

Strong tectonic inversion of the Polish-Danish Trough, related to the Laramide phase, caused an uplift of the Meso- 


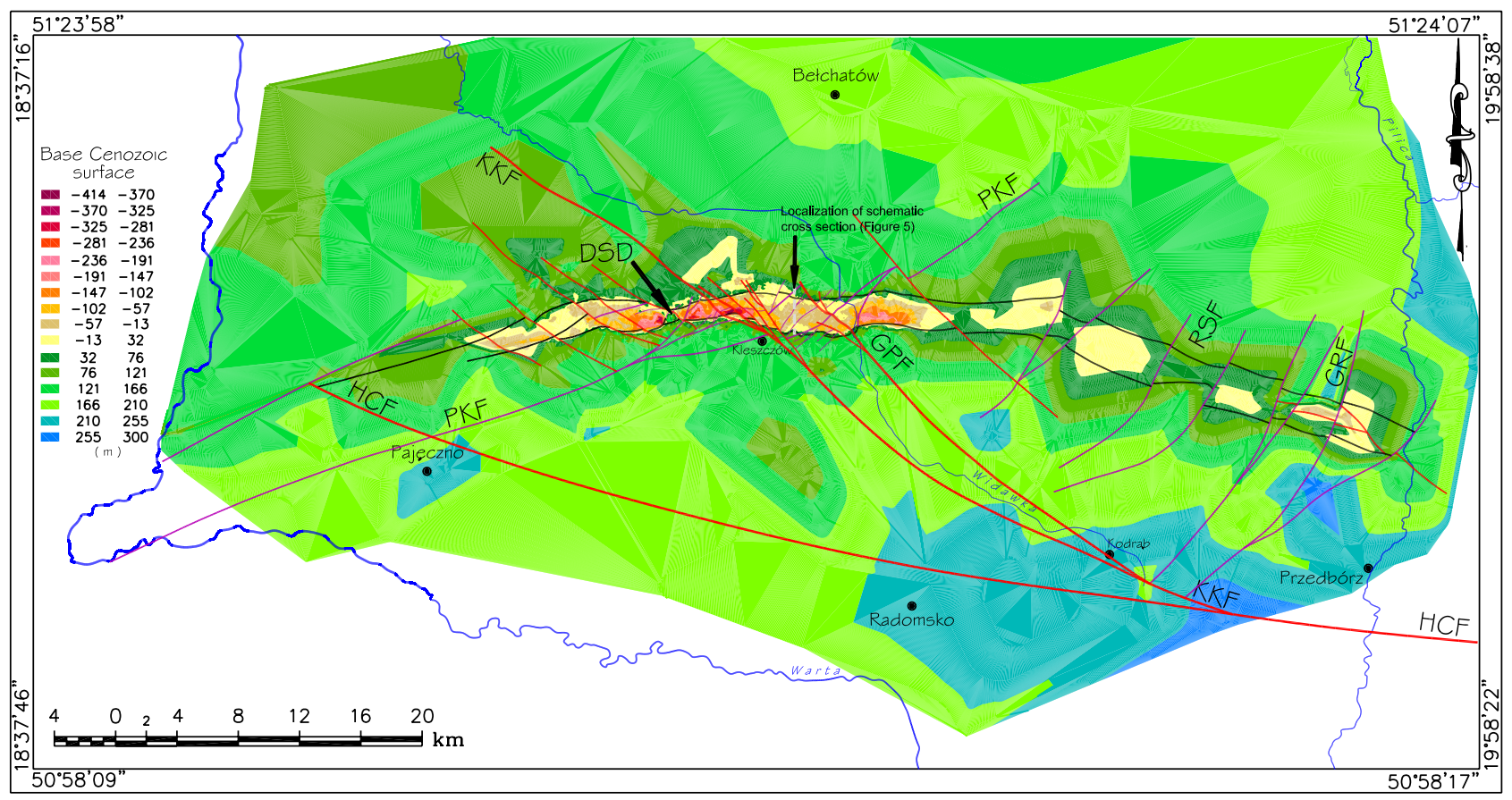

Fig. 4. Structural map of the base Cenozoic surface in the Kleszczów Graben area. Abbreviations as in Fig. 3.

zoic sediments. The main deformation in the studied area took place, presumably, in the Early Paleogene. This is suggested by the retained continuity, revealed in numerous boreholes in the graben area, between the uppermost members of the upper Mastrichtian and the lowermost Tertiary strata (Danian-Montian; Błaszkiewicz et al., 1987). The NE-SW compressional shortening produced en-echelon folds with NW-SE axes, in the most uplifted zone of the adjacent to the Kleszczów Graben the Radomsko Elevation (Pożaryski, 1971). In the map view, the folds display S-shape, which suggests that they originated in a sinistral wrench movement over the westward prolongation of the HCF (Pożaryski, 1974). Some of these folds pass into the Łódź Depression, crossing the area of the future Kleszczów Graben. The most conspicuous among them is the Łȩkińsko Anticline, which extends within a considerable area from the "Bełchatów" mine (Figs. 3, 4). Further movements produced the ENEWSW, NW-SE and WNW-ESE trending faults, some of which resulted from a partial reactivation of the older dislocations (Figs. 2, 4). The NW-SE striking faults, longitudinal with respect to the folds, were transformed into reverse structures due to dextral, transpressive displacements along the Teisseyre-Tornquist zone (Mogensen 1995). In the Kleszczów Graben area, the Late Paleogene is represented by an erosional gap, which resulted from the upwarping of the area in front of the Carpathians. The residue from this process can be represented by a characteristic layer of quartz conglomerate and quartzose sandstone, reported from the boreholes. This quartz-rich layer separates the underlying, micropalaeotologically dated, Danian-Montian sediments from the overlying, lowermost members of the
Miocene brown coal series (Gotowała, Hałuszczak 1999).

\section{The structural framework of the graben}

The principal macrostructural features of the Kleszczów Graben, including the bounding and transverse faults, have been inferred from a detailed reconstruction of the subCenozoic surface (borehole results) and structure analysis (field observations in the open-pit mine) (Fig. 4). In the studied area, the elevation of the sub-Cenozoic surface varies from $-414 \mathrm{~m}$ in the most subsided parts (between the Dębina Salt Dome and the Łękińsko Anticline) to $+300 \mathrm{~m}$ in the southeastern part, outside the Kleszczów Graben. A fairly continuous belt of depressions shown on the map (Fig. 4) defines the evidently arcuate trend of the Kleszczów Graben that starts from the Warta river in the west and ends on the Pilica river in the east. The western termination of the graben, formed by a narrow and gradually dying-out depressions, extends along the regional BKF-PKF fault zone (Figs. 1, 4). The easternmost, much shallower segments of the graben are dominated by isolated, reaching the depth of $-66,6 \mathrm{~m}$ depressions in the top-Mesozoic surface. The spatial arrangement of these depressions and their elongation appear to be controlled by tectonic lines, which trend 290 $110^{\circ}$, and coincide with the direction of the HCF.

The best known, central part of the Kleszczów Graben, the coalfield "Bełchatów", is characterized by notable depths of sub-Cenozoic surface that reach, on average, $-150 \mathrm{~m}$ to $-250 \mathrm{~m}$. Variations in the morphology of this surface in the graben show a clear relationship with the underlaying 


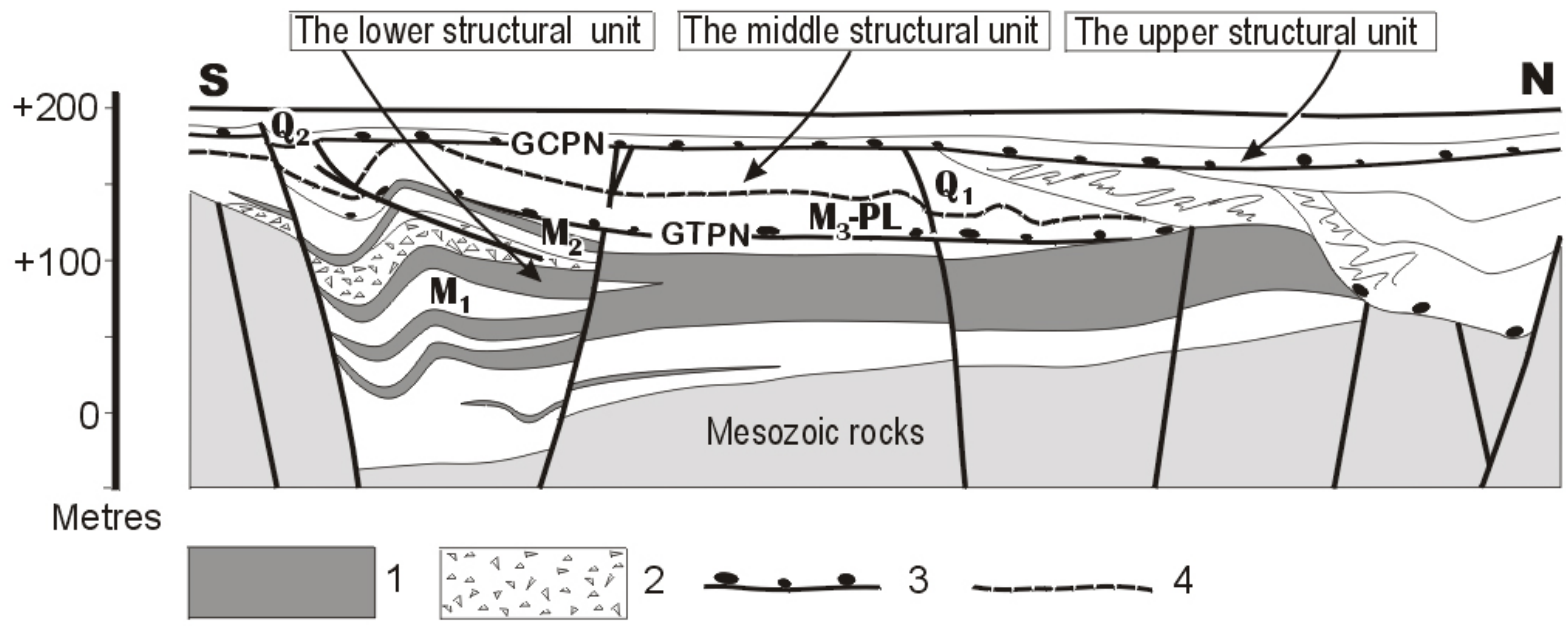

Fig. 5. Schematic cross section of the Kleszczów Graben - (2 x exaggerated). Notations are: 1) brown coal seems; 2$)$ sedimentary breccias; 3) main angular unconformities; 4) Tertiary/Quaternary boundary. Abbreviations are: GTPN - top surface of the lower structural unit; GCPN - top surface of the middle structural unit; M1 - Lower Miocene; M2 - Middle Miocene; M3-P1 - Upper Miocene to Pliocene; Q1 - Elsterian to Saalian; Q2 - Inter Saalian to Holocene.

Laramide structure pattern (Figs. 2, 4). The most spectacular example of this pattern is the area of the Łȩkińsko Anticline, with the distinctly elevated Mesozoic top surface (the hinge area) and associated depressions related to the limbs of the anticline (Fig. 4).

The southern and northern borders of the graben are formed by complex, straight fault segments of various sizes, that strike NW-SE, NE-SW, WSW-ENE and WNW-ENE. The two last directions predominate in the eastern and western parts of the area, respectively. In some places, the southern margin is formed by sets of faults, which form the steplike pattern, when viewed in a vertical cross section. In general, the southern bounding faults are much more expressed, having throws of up to several hundred metres. Extensive transverse faults, which separate the graben into individual segments, are characteristic features of its frame structures seen on map (Fig. 4 ). Some of them have been defined as related to the regional size dislocations, such as the KKF, GPF, RSF, and the GRF.

Summing up, the present day structural framework of Kleszczów Graben is dominated by the NW-SE, NE-SW, WSW-ENE and WNW-ENE trending faults, and can be considered as inherited from the Laramide and older tectonic events that occurred within the studied area. This has been confirmed, as well, by the results of the satellite image analyses (Graniczny, 1980, Karnkowski, 1980).

\section{The main structural units of the graben's sedimentary infill}

The Cenozoic deposits of the Kleszczów Graben, exposed in the "Bełchatów" mine, display distinct vertical differences in their structural characteristics. These include the style and the intensity of deformation as well as different structural patterns that define a number of structural levels. The three main distinguished units, which are bounded by angular unconformities (GTPN, GCPN) (Figs. 5, 6), in many respects resemble structural levels (sensu e.g. Pożaryski, Tomczyk, 1969).

The lower structural unit of the Lower and, partly, of the Middle Miocene (up to Badenian) age, is composed of subcoal sandy deposits, the main coal seam as well as secondary coal beds, together with the accompanying coaled clays. The top of the lower unit is formed by the erosional surface GTPN, dated as of Upper Middle Miocene/Late Miocene, that crosscuts folds and faults in the coal and coal-bearing sediments. The overlying, clayey-sandy sediments, which represent the Late Miocene (and/or Pliocene?) and the lower part of the Quaternary (up to the Saalian-Odra Glaciation), belong to the middle structural unit. The well-developed deformational structures in this sequence are cut by the erosional surface GCPN, which is believed to be a correlative with the Inter Saalian (Pilica Interstadial). The overlying, relatively undisturbed Quaternary (Inter Saalian to, and including, the Holocene) strata form the upper structural unit (Fig. 5).

\section{Structural evolution of the Kleszczów Graben}

According to the drill hole data and mesostructural field observations, the Tertiary-Quaternary evolution of the Kleszczów Graben can be divided into three stages.

7.1 Stage I - the opening and growth of the graben (Early to Middle Miocene)

The initial stage of development of the graben's depression is reflected in sandy-muddy sediments of the sub-coal series, 


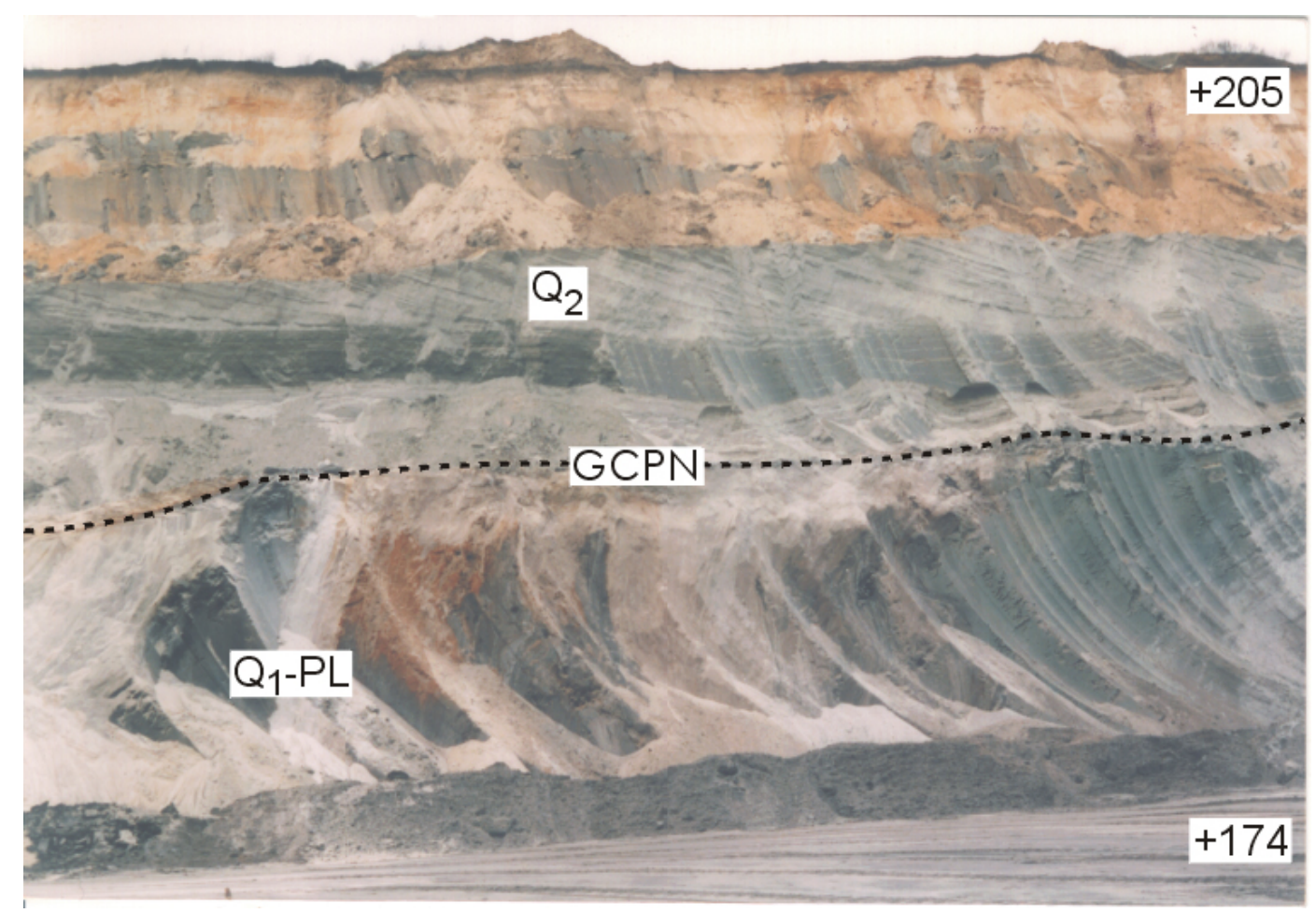

Fig. 6. Subhorizontal layers of the Warthian glacial deposits resting along the GCPN angular unconformity on strongly eroded, tightly folded late Tertiary-Elsterian sequences. The uppermost escarpment of the open-pit mine "Bełchatów". Abbreviations are: GCPN - main angular unconformity - top surface of the middle structural unit; Q1-PL - Pliocene and Lower Quaternary sediments; Q2 - Inter Saalian to Holocene.

which show variable thickness and facies aspects, reflecting the existence of several depositional centres. Paleobotanical dating of organic-rich interlayers in the lower part of the subcoal deposits (Stuchlik et al., 1990, 1998) suggests that subsidence started during the earliest Miocene or at the turn of Oligocene/Early Miocene. The overlying thick, coal-bearing deposits (including the so-called main seam and secondary coal beds) correspond to a steady and slow subsidence that lasted until the turn of Karpatian/Badenian (16.5 1.3 ; FT dating of zircons from tuffite B; Burchart et al., 1988).

The main events of this stage are reconstructed from the macrostructural analysis of the base Cenozoic surface of the Kleszczów Graben, in reference to the main features of the depositional architecture of the Early Miocene. A particularly important role is attributed to the Brzeg-KluczborkBełchatów Fault (BKF), cutting across the meander of the Warta river near Działoszyn, which propagation toward the ENE as the PKF commences the opening of the graben structure (Figs. 4, 7) (Gotowała, 1999, Gotowała, Hałuszczak, 1999). This ENE-WSW trending fault, originates within the area of the Fore-Sudetic Monocline and extends to the ENE in a form of branching, right stepping, en-echelon fault set, which defines the main, bounding structures of the graben. The incipient subsidence centres of the primary basins, at the time of the opening, are shown on the map (Fig. 4) as isolated maximum depressions in the base Cenozoic surface. A pull-apart origin of these depressions is indicated by their po- sition between segments of en-echelon pattern of the graben boundary faults.

The NW-SE faults, which were active during that period, controlled the transversely directed differentiation of the sedimentary basins. These were infilled by sandy clayey and, later, by clayey-peat and peat sediments. They formed, together with the bounding ENE-WSW faults, a conjugate fault system affected by the WNW-ESE to NW-SE directed compression during the Early Miocene. This stress pattern triggered strike-slip displacements on the main faults of the Kleszczów Graben, with the dextral shear-sense on the ENEWSW and NE-SW faults and the sinistral shear-sense on the NW-SE faults (Fig. 7). This resulted in a growth of initial, isolated subsidence centres, clearly developed in the western and central parts of the graben. In the eastern part of the graben, where the NE-SW and ESE-WNW trending faults are at a higher angle and the pull-apart phenomena are restricted to NE-SW directions, the population of primary basins is poorly developed (Figs. 4, 7).

The compressional stress pattern, as related to the European-African plate convergence and collision events, has been reported from the Alpine Foreland platform. The Neogene compressional structures are known from a zone of hundreds kilometres wide within the present Alpine front (Letouzey 1986). An analogous zone has been probably formed north of the Carpathian thrust, but because lack of fair outcrop conditions, field evidences are not numerous. 


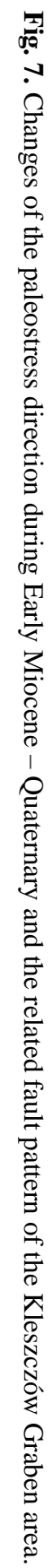

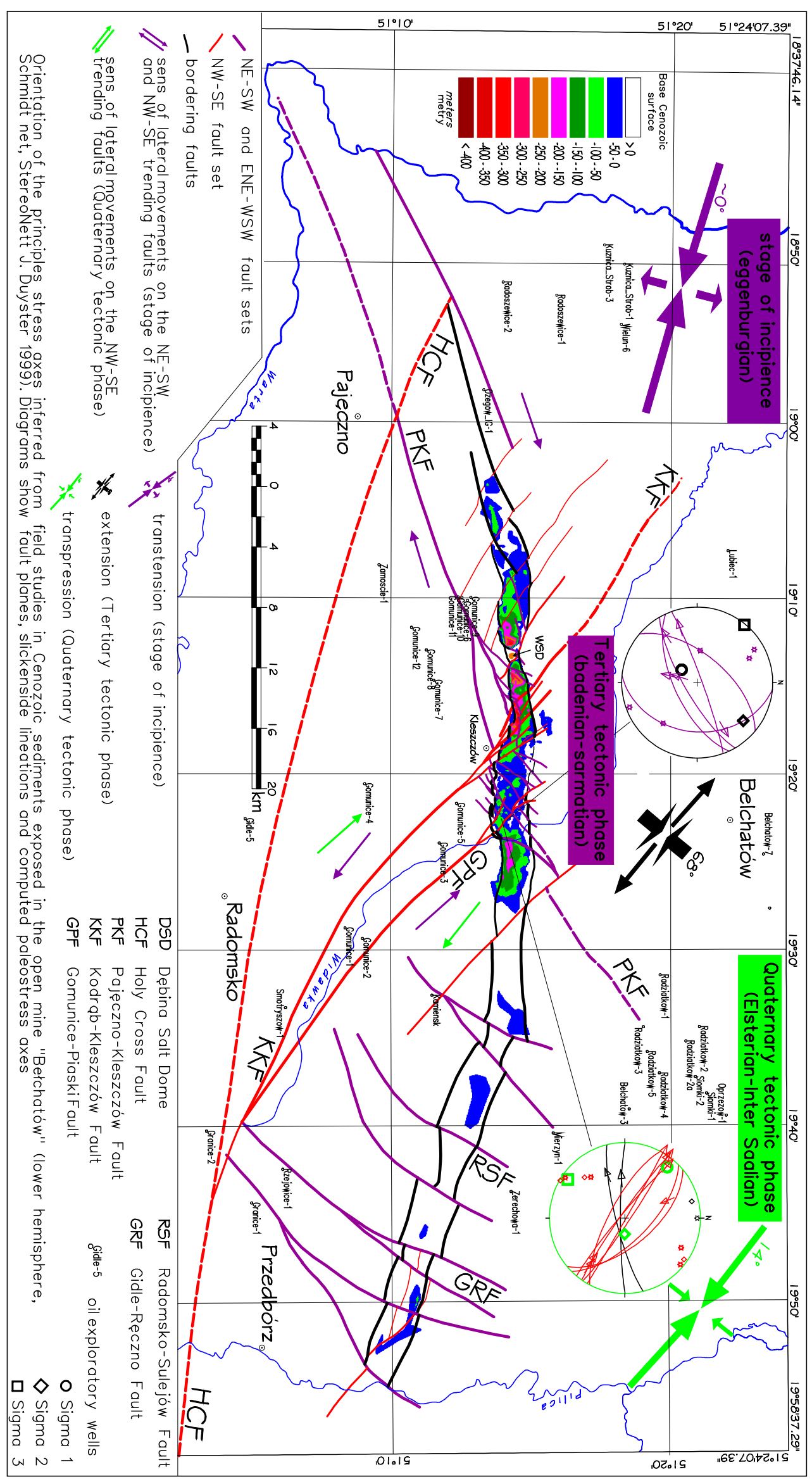




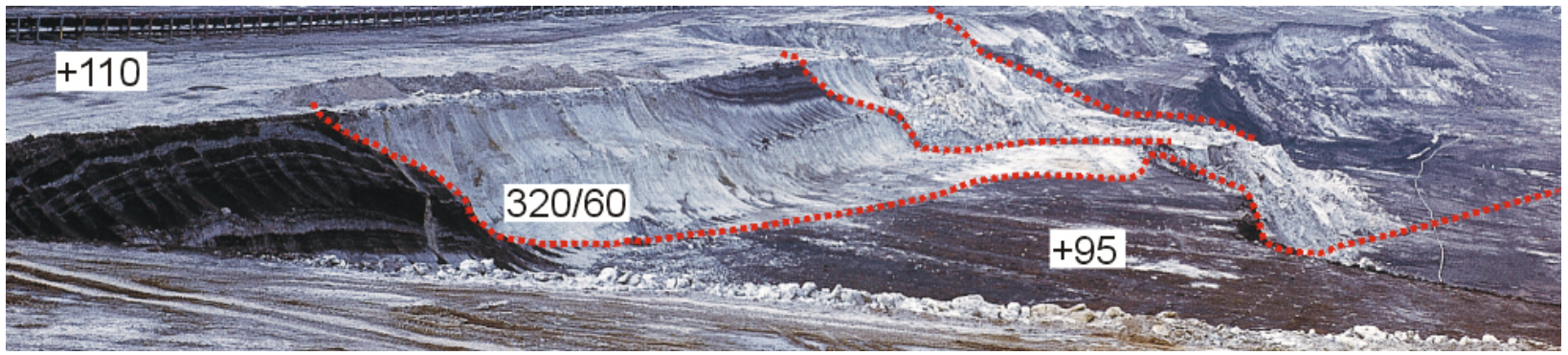

Fig. 8. Several NE-SW trending, normal faults within the Middle Miocene strata of the middle structural unit. The fault in the foreground separates the brown coal seems (foot wall) and coarse-clastic sediments (hanging wall). The displacement is about $30 \mathrm{~m}$. View from the southern slope of the open-pit mine "Bełchatów" towards exploitation escarpments, about $100 \mathrm{~m}$ below ground surface. Measurement convention: dip-direction/dip.

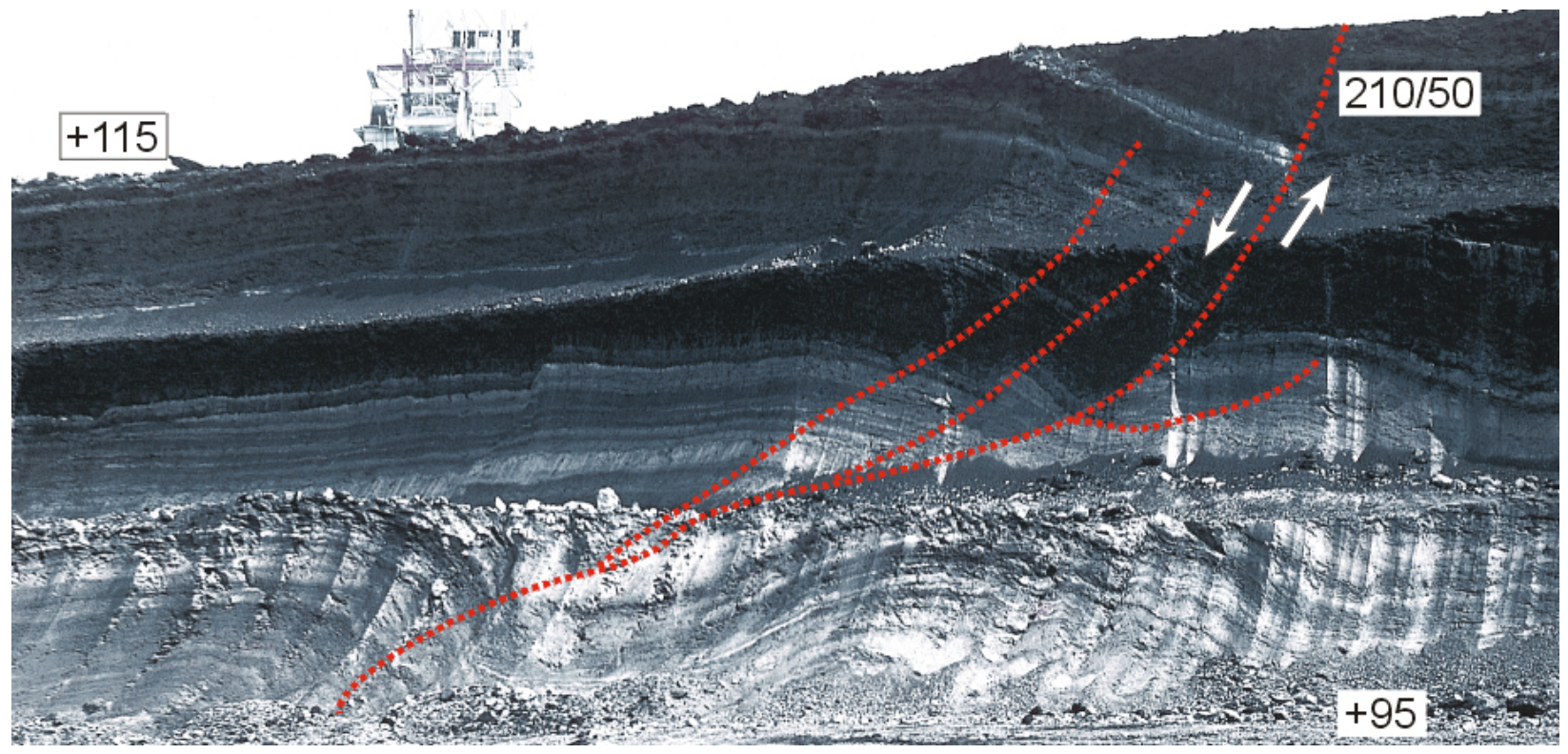

Fig. 9. NW-SE trending fault pattern and related rollover anticlines in the brown coal layers and lacustrine limestones (Middle Miocene). The lower structural unit. Western escarpment of the open-pit mine "Bełchatów", about $90 \mathrm{~m}$ below ground surface. Measurement convention: dip-direction/dip.

During the final phase of organic sedimentation, after the deposition of the uppermost coal beds (the end of Karpatian), a gradual change took place in the orientation of the principal compressional stress, from the horizontal to vertical and/or oblique. Above the reactivated ENE-WSW faults at depth, en-echelon pattern of normal faults developed, which belonged, partly, to the graben fault bounding system.

The first stage of the structural evolution ended with a phase of a strong tectonic activity, recorded by numerous faults and folds in coal-bearing Miocene sediments exposed in the "Bełchatów" mine (Figs. 8, 9). Major NE-SE normal faults cut across the graben and formed secondary, diagonal depressions that were used during a transport of coarseclastic material produced by the erosion of the Jurassic rocks on the graben margins. The faults displace, as well, the main coal seam by ca. 20-30 $\mathrm{m}$ and continue in the Mesozoic strata, as indicated by the drilling results.
The field observations of shear-sense indicators on the NESW fault planes, which represent the main structural direction of the lower structural unit, indicate that they are normal faults with a minor strike-slip component (Fig. 7). However, it is not clear if these conditions remained unchanged also during the final phase of the Tertiary activity in the Kleszczów Graben. In the northern, marginal part of the Carpathian Foredeep, two phases of Middle/Late Miocene tectonic movements have been documented (Krysiak, 1985). The first phase, at the turn of Badenian/Sarmatian, was characterised mainly by normal faulting, whereas the second phase, post-Sarmatian, took place under conditions of a definite horizontal compression that produced strike-slip and oblique-slip faults.

A general uplift of the entire zone of the Kleszczów Graben, due to Middle Miocene movements, is indicated by a pronounced erosion that, locally, reached the top of the 


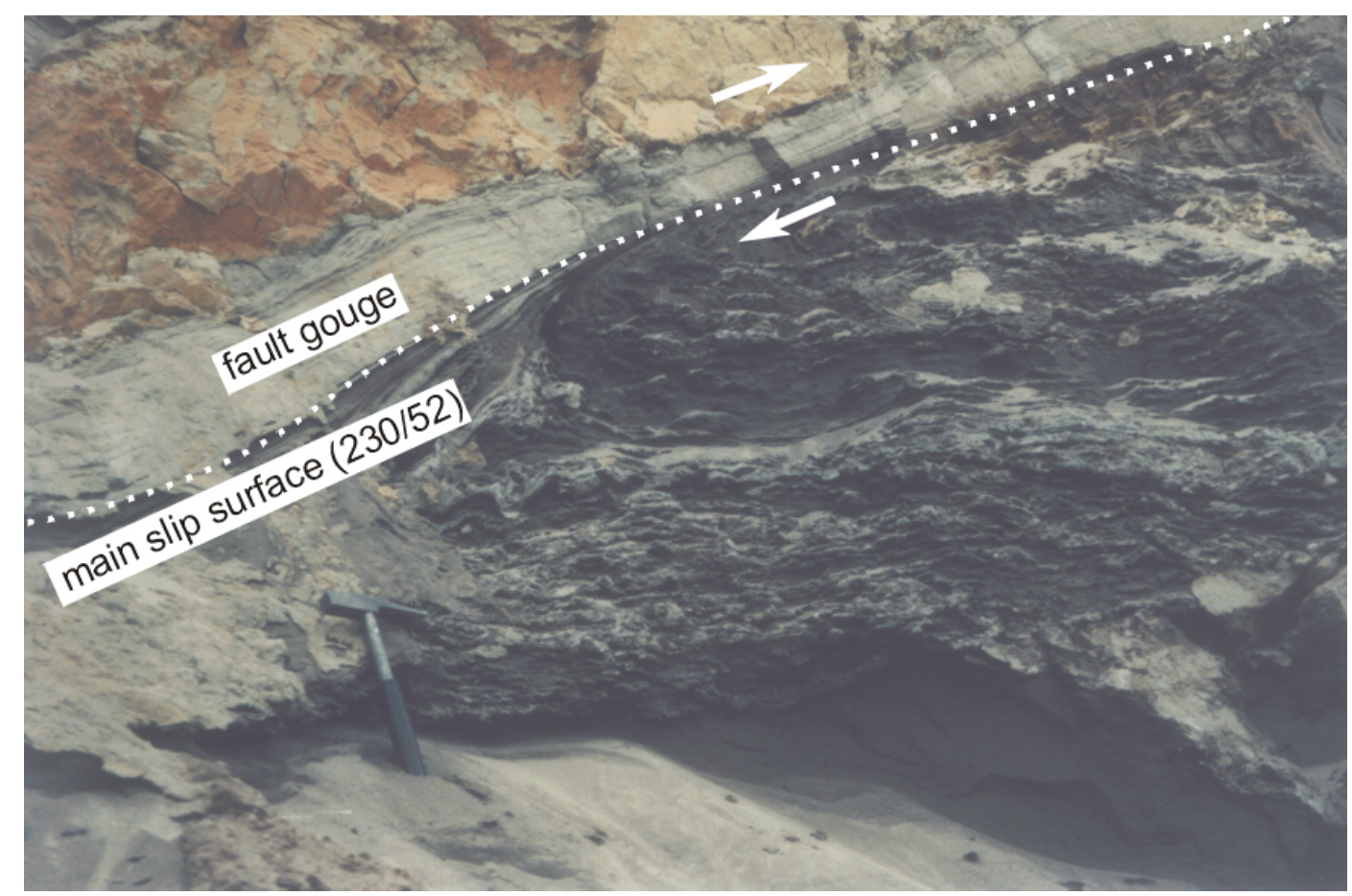

Fig. 10. Reverse drag fold related to thrust movements along Folwark Fault, in a coarse sands of the Upper Miocene age. The middle structural unit. The western escarpment of the open-pit mine "Bełchatów", about $95 \mathrm{~m}$ below ground surface. Measurement convention: dip-direction/dip.

main coal seam. This resulted in the GTPN unconformity which represents a boundary with the sequence of the Late Miocene, Pliocene and Early Quaternary (i.e. the middle structural unit).

In the foreland of the West Carpathians and the Alps (West European platform province), the Tertiary tectonic activity led to a development of major graben systems, with the initial rift stage occurring in the Eocene-Early Oligocene. At that time the Rhine Graben formed, as did grabens of the southwestern France and the North Sea (Ziegler 1995). In Poland, similar grabens developed in the end of Paleogene and beginning of Miocene times are known from the NE part of the Fore-Sudetic Monocline (Fig. 1). They include the grabens of the Poznan-Oleśnica fault zone (Oberc, 1972) and the grabens from the marginal zone of the Fore-Sudetic Monocline, between Poznan and Przedbórz (Dạbrowski, 1980; Deczkowsk, Gajewska, 1983). The time of the initial opening of these grabens was progressively younger towards the SE, thus grabens in the northwest (e.g. the Paleogene Gostyń graben) were initiated earlier, whereas those in the southeastern part of the Monocline (e.g. Early Miocene Złoczew graben) were established later (Deczkowski, Gajewska 1983).

With reference to the timing of the Carpathians events, it is suggested that the beginning of the Kleszczów Graben, as a pull-apart type, initial depressions, as well as the main opening stage, occurred during the extrusion of the Western Carpathians (part of ALCAPA microplate). The later event took place from Eggenburgian to Karpatian (Ratschbacher et

\section{al. 1991).}

The ending of the stage I in the evolution of the Kleszczów Graben can be correlated with the final thrusting of the Outer Carpathians towards NE that, in their Polish part, took place in Middle Sarmatian ( Oszczypko, Ślączka 1989 ).

\subsection{Stage II - structural re-arrangement of the graben (Lat- est Tertiary to Middle Quaternary)}

This stage includes a time interval between the Late Miocene and the Middle Quaternary - Inter Saalian (Pilica Interstadial) (Fig. 5). A significant part of this interval, corresponding to the deposition of the coal-free, sandy-clayey Tertiary strata (Late Miocene to Pliocene?) and of the oldest Quaternary deposits, is characterised by a negligible tectonic activity and a low rate subsidence in the graben zone (Wilczyński 1992, Hałuszczak 1995). Nevertheless, on the maps of Krzyszkowski (1992) that show the lateral extent of formations related to the Elsterian (South Poland Glaciation) one can still notice some minor influence of NE-SW faults, so characteristic for the lower structural unit.

The structural record present in the Cenozoic deposits of the Bełchatów mine shows a visible increase in the tectonic activity starting with the end of the Elsterian and waning on the Saalian. The Quaternary tectonic activity resulted in the creation of a new fault generation, of mainly NW-SE trend, and in folding of the Cenozoic strata. Some of the already existing NE-SW faults were also reactivated. These intense deformations controlled, as well, a remarkable differentia- 


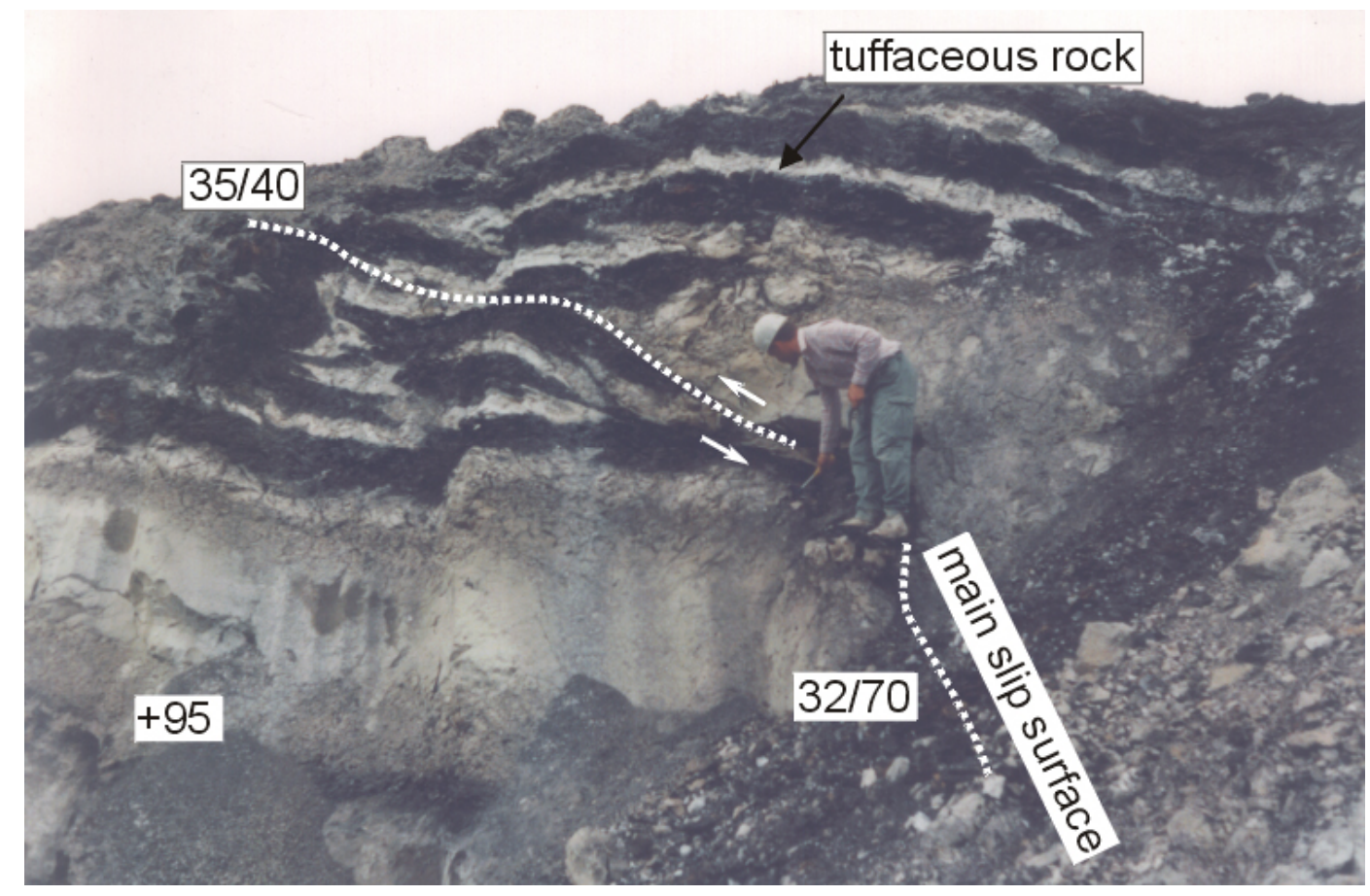

Fig. 11. Numerous small thrust faults associated with the overturned or recumbent folds in the Middle Miocene sediments (clays, brown coal, tuffites). Note the replacement of the main fault surface by a series of imbricate splay faults. Presented here structures form the southern termination of the Folwark Fault zone. The middle structural unit. The western escarpment of the open-pit mine "Bełchatów", about $80 \mathrm{~m}$ below ground surface. Measurement convention: dip-direction/dip.

tion of facies within the Quaternary sediments, in particular, in those of the Saalian age.

An integrated analysis of meso- and macrostructural data, indicated that the transpressional stress regime, in this developmental stage, was characterized by the principal maximum compression axis along the NW-SE direction (Gotowała 1999). The NW-SE trending, dextral strike-slip faults (GPF, KKF) were reactivated in the graben's basement, restoring the structural pattern of the main Laramide transpression stage. The earlier structures in the graben zone, related mainly to WSW-ENE and ESE-WNW directions, were overprinted by a homogeneous, NW-SE-dominated, structural pattern. The mechanisms and structural effects of this deformation stage were controlled by strike-slip displacements on the main, originally reverse, NW-SE striking, fault planes. The reactivated Laramide fold system in the basement of the graben caused a distinct variation in the thickness pattern of the Upper Tertiary and Quaternary sedimentary cover (Fig. 4). Reverse kinematic characteristics of the main fault zones on the NE and SW limbs of the Łękińsko Anticline (the GPF and the KKF, respectively) (Figs. 4, 7), combined with the dextral displacements occurring during that period, led to a restoration of a palm-tree type anticline that dates back to the Laramide deformation (Gotowała 1999). The transpressive deformation phase, which took place during this stage of the graben's development, has been recorded on a macro-scale by offsets of the main bounding faults, as well as, by the lateral extent of the brown-coal seems. A deep exposure of the KKF zone during exploitation works, revealed an existence of a major, NE-directed thrust (Folwark Fault) in the Tertiary-Quaternary strata (Hałuszczak et al., 1995; Hałuszczak, 1999) (Figs. 10, 11). The frontal zone of the thrust surface dips, on average, $45^{\circ}$ and strikes NW-SE to W-E, whereas deeper, the thrust surface merges into a subhorizontal flat. The southern limit of the entire structure is defined by a set of folds, confined to strata of the same age (Fig. 5). The folds are thrusted and show a strong, southward asymmetry. Taken together, the described tectonic features are thought to represent a compressional/transpressional pop-up structure, corresponding to shallow intersection levels of a deeply rooted, palm-tree type structure, occurring within the KKF zone (Hałuszczak, 1999).

Like the first stage of the Kleszczów Graben development, the second stage ended, as well, with the erosional phase, that formed the angular GCPN unconformity, covered by sedimentary rocks of the upper structural unit (Figs. 5, 6).

\subsection{Stage III - late Quaternary to recent activity}

This stage corresponds to a period of sedimentation that includes the Inter Saalian up to Holocene, and constitutes of a relatively short time interval (ca 260 thousand years). The Warthian (Warta Glaciation) deposits, which dominate the younger structural unit, are usually subhorizontal, and do not show any stronger, or widely distributed deformation. 
However, vertical movements along the bounding faults of the graben, were revealed by mesostructural observations in varve clays of the lowermost member of the Warthian series. Presumably, near the end of the clay sedimentation period, the graben boundary faults became reactivated, what led to the seismic-generated gravitational slumping and folding in these sediments (Gotowała, 1982, 1999). A later, deep erosional dissection of the varve clays that occurred before the ice sheet transgression, might have been related to a renewed activation of the NW-SE trending faults. This reactivation is evidenced by the uplift, along the faults, of some of the structural blocks in the basement (e.g. Łękińsko Anticline). The Kleszczów Graben area was covered by the ice sheet and, in consequence, by glacial deposits reflecting two (Hałuszczak, 1982; Brodzikowski, 1985) or even three (Krzyszkowski, 1992) phases of the transgression, which was contemporaneous with a successive reactivation of the graben's boundary faults and their further development in younger horizons. As a result, there is a clear increase in thickness of glacial clays above the southern bounding faults of the graben accompanied by a concentration of glacitectonic deformations (Brodzikowski, 1985).

The presented observations point to some activity of the border faults even during the youngest Quaternary, although the intensity of the deformation is assessed as distinctly lower than that of the earlier episodes.

Seismic events, partly induced by the exploitation in the open-pit mine "Bełchatów", are the expression of recent tectonic activity of the Kleszczów Graben. Only during the period of 1978-92, nearly 1200 earthquakes have been recorded, most of which were of magnitude less than 1 . The strongest earthquake, with magnitude of 4.6 was recorded in the GPF fault zone. The earthquake's focal depth was estimated at ca $2 \mathrm{~km}$. The focal mechanism solution (Gibowicz et al., 1983) suggests a fault displacement with the obliqueslip shear-sense, and an attitude of one of the nodal planes strictly conforming to the NW-SE trend of the GPF (Fig. 4, 7). Following the progress of the exploitation in the mine towards the west, a new seismically active zone (tremors of 1.9 to 3.7 in magnitude) appeared along the KKF zone and along some segments of the graben border faults.

\section{Conclusions}

The Late Alpine Kleszczów Graben and its surroundings are located in a zone of the intersection of deep-seated, regional dislocations, such as the HCF and the BKF, that resulted from the earlier tectonic events: the Early and Middle Alpine, or even Variscan. The reactivation of these faults during the Tertiary-Quaternary pre-determined the present day structural framework of the Kleszczów Graben (faults trending NW-SE, NE-SW, WSW-ENE and WNW-ENE), and thickness and facies distribution of its sedimentary infill.

An integrated meso- and macrostructural data-set have been used to characterize the successive directions of stress field during the polyphase history of the Kleszczów Graben.
The graben opened in the Late Oligocene-Early Miocene, as a result of the reactivation, in transtensional regime with the WNW-ESE compression, of the WSW-ENE and NWSE trending, pre-existing faults. Related pull-apart basins have been created successively and modified subsequently, producing continuous, fault-bordered depressions. The longlasting, organic sedimentation resulted in the deposition of thick layers of brown coal. In the final phase of this sedimentation (Middle Miocene, Badenian), a gradual change took place in the orientation of the principal compressional stress, from the horizontal to vertical (or oblique). Above the reactivated, ENE-WSW trending faults in the basement, en-echelon pattern of NE-SW normal faults developed in the coal-bearing sediments of the graben.

Following the period of tectonic quiescence (Late Miocene to Elsterian), the NW-SE trending faults in the basement were reactivated in the same mode as during the Laramide event (i.e NW-SE compression). Reverse, dextral strike-slip movements along the NW trending faults (GPF and KKF) resulted in the folding and faulting (Elsterian to Saalian) of the graben's sedimentary infill. Of special interest are thrusts and reverse faults, which can be related to the shallow intersection levels of transpressional, palm-tree type fault structure, deeply rooted in the KKF zone.

The last stage of the graben's structural evolution (Inter Saalian up to the Holocene) is characterized by a relatively minor tectonic activity. Vertical movements along the bounding faults occurred as a result of glacial unloading or rebound, coupled with mobility of the deep-rooted fault zone. The recent record of seismic events in the "Bełchatów" mine area, reveals their clear relationship to the frame faults of the graben.

Acknowledgement. Authors are indebted to Michal Kováč and one anonymous reviewer for the comments and valuable suggestions that considerably improved this paper. Special thanks are addressed to our colleague Z. Szybiński for his corrections on final version of the article.

Presented paper was prepared as a part of the research financed by the grant from the Polish Research Committee KBN No.6 PO4D 03712 .

\section{References}

Bac-Moszaszwili, M. and Morawska, A.: Tectonic structures in the Cretaceous formations of Warsaw basin and their relation to the substratum dislocations, Acta Geol. Pol., vol. 25 (4), 577-587, 1975.

Baraniecka, M. D.: Staroczwartorzędowe rowy tektoniczne i ich osady, Kwart. Geol., 15, (2), 358-370, 1971.

Baraniecka, M. D.: Fazy tektoniczne w czwartorzȩdzie w środkowej czȩści Niżu Polskiego, Materiały I Sympozjum "Współczesne i neotektoniczne ruchy skorupy ziemskiej w Polsce", T. I, 186-195, 1975.

Baraniecka, M. D.: Dotychczasowe i bieżące badania czwartorzȩdu rejonu Bełchatowa, in: Przewodnik I Sympozjum "Czwartorzęd rejonu Bełchatowa", 1-13, 1982. 
Błaszkiewicz, A., Dadlez, J., Da̧browska, Z., Gawor-Biedowa, B., Karaczewski, L., Kopik, J., Malinowska, L., Radlicz, K., and Styk, O.: Opis wierceń, Mat. arch., Field raport, Wrocław, 1987.

Bogacz, W. and Kopka, M.: Uwagi o genezie rowu tektonicznego Bełchatowa w świetle badań wykonanych w obrȩbie wkopu udostępniającego, Zeszyty AGH - Geologia 7 (2), 111-118, 1981.

Brodzikowski, K.: Glacial deformation environment in the subsiding zone with special references to the Kleszczów tectonic graben, Quaternary studies in Poland, 6, 5-22, 1985.

Brodzikowski, K., Gotowała, R., Kasza, L., and Van Loon, A. J.: The Kleszczów Graben (central Poland) reconstruction of the deformational history and inventory of the resulting soft - sediment deformantional strctures, in: Deformantion of sediments and sedimentary rocks, Geol. Soc. Spec. Publ., 29, 241-253, 1987.

Burchart, J., Kasza, L., and Lorenc, S.: Fissiontrack zircon dating of tuffitic intercalations (Tonstein) in the Brown-Coal Mine "Bełchatów", Bull. Pol. Acad. Scien., 36, 281-286, 1988.

Dadlez, R.: Epikontinental basins in Poland: Devonian to Cretaceous-relationships between the crystalline basement and sedimentary infill, Geological Quarterly, 41, 4, 419-432, 1997.

Dąbrowski, A.: System rowów trzeciorzędowych w obrazie grawimetrycznym, Prz. Geol., 28 (3), 169-171, 1980.

Deczkowski, Zb. and Gajewska, I.: Budowa geologiczna podłoża retyku obszaru monokliny przedsudeckiej, Kwart. Geol., 23 (1), 161-174, 1979.

Deczkowski, Zb. and Gajewska, I.: Budowa geologiczna podłoża trzeciorzędu w rowach Złoczewa i Gostynia (monoklina przedsudecka), Kwart. Geol., 27 (3), 535-546, 1983.

Gibowicz, S., Guterch, B., Lewandowska-Marciniak, H., and Wysokiński, L.: Seismicity induced by surface mining; the Bełchatów, Poland, earthquake of 29 November 1980, Acta Geoph. Pol., 30 (3), 193-219, 1983.

Głazek, J.: Paleokarts of Poland, in: Paleokarst. A systematic and regional review, Academia Prague, Elsevier Scien. Publ., 77105,1989

Gotowała, R.: Tektonika i wykształcenie strukturalne czwartorzędu w rejonach Piaski i Buczyna-Chojny, in: Przewodnik I Sympozjum "Czwartorzȩd rejonu Bełchatowa", 41-65, 1982.

Gotowała, R.: Zarys budowy struktualnej mezozoiku i trzeciorzędu odkrywki Bełchatów, in: Przewodnik II Sympozjum "Czwartorzȩd rejonu Bełchatowa", 206-213, 1987.

Gotowała, R.: Model tektoniki rowu Kleszczowa - interpretacja danych z wykorzystaniem metod komputerowych. Materiały konferencyjne: Tektonika rowu Kleszczowa - stan badań i gówne zadania w aspekcie eksploatacji górniczej, Bełchatów, 20-21 października 1994, 91-103, 1994.

Gotowała, R.: Tektonika rowu Kleszczowa na tle geologii regionu Bełchatowa, Ph. D. thesis, Inst. of Geol. Sci. Univ. Wrocław, 1999.

Gotowała, R. and Hałuszczak, A.: Pozycja i główne etapy młodoalpejskiego rozwoju rowu Kleszczowa w świetle badań mezostrukturalnych w odkrywce KWB "Bełchatów" i numerycznej analizy wyników wierceń, in: Młodoalpejski rów Kleszczowa: rozwój i uwarunkowania w tektonice regionu. Odkrywka KWB Bełchatów i obszar radomszczańsko-wieluńsko-łódzki, Konferencja naukowa - Słok k. Bełchatowa 15-16 października 1999, 23-38, 1999.

Graniczny, M.: Bełchatowskie zagłębie wȩglowe jako fotogeologiczny poligon testowy in: Przewodnik 52 Zjazdu PTG, Bełchatów, 184-197, 1980.
Hakenberg, M.: Dependence of the thickness of Permian to Jurassic sediments in the Miechów Basin on major faults, Acta Geol. Pol., 30 (4), 471-482, 1980.

Hałuszczak, A.: Zarys budowy geologicznej czwartorzędu w rejonach Piaski i Buczyna-Chojny, in: Przewodnik I Sympozjum "Czwartorzęd rejonu Bełchatowa", 14-35, 1982.

Hałuszczak, A.: Struktury tektoniczne w osadach nadwȩglowych zachodniej części odkrywki KWB "Bełchatów", Ph. D. thesis, Inst. of Geol. Sci. Univ., Wrocław, 1995.

Hałuszczak, A.: Struktury deformacyjne o cechach kontrakcyjnych w utworach trzeciorzȩdowych zachodniej czȩści odkrywki KWB "Bełchatów" i problem ich genezy, in: Młodoalpejski rów Kleszczowa: rozwój i uwarunkowania w tektonice regionu. Odkrywka KWB Bełchatów i obszar radomszczańsko-wieluńskołódzki. Konferencja naukowa - Słok k. Bełchatowa 15-16 października 1999, 39-48, 1999.

Hałuszczak, A., Gotowała R., and Czarnecki, L.: Uskok Folwarku - przejawy tektoniki przesuwczej w zachodniej częœci odkrywki Bełchatów, Przegląd Geologiczny, 43, 5, 409-411, 1995.

Karnkowski, P. H.: Elewacja radomszczańska w świetle geologicznej interpretacji zdjęć satelitarnych, Prz. Geol., 28 (7), 413415,1980

Kossowski, L.: Budowa geologiczna złoża wȩgla brunatnego Bełchatów ze szczególnym uwzględnieniem tektoniki podłoża, Górnictwo Odkrywkowe, 10-11, 336-344, 1974.

Krysiak, Z.: Rola mechanizmów tektonicznych w procesach powstawania złóż siarki w Machowie, Przeg. Geol., 33, 458-460, 1985.

Krzyszkowski, D.: The tectonic deformation of quaternary deposits within the Kleszczów graben, Central Poland, Tectonophysics, 163, 285-287, 1989.

Krzyszkowski, D.: Czwartorzęd rowu Kleszczowa, Litostratygrafia i tektonika, Studia Geograficzne 54, Wyd. Uniw, Wrocław, 1992.

Letouzey, J.: Cenozoic paleo-stress pattern in the Alpine Foreland and structural interpretation in a platform basin, Tectonophysics, 132 (1-3), 215-231, 1986.

Marek, S. (red.): Budowa geologiczna niecki warszawskiej (płockiej) i jej podłoża, Prace Instytutu Geologicznego CIII, PIG, Warszawa, 1983.

Mogensen, T. E.: Triassic and Jurassic structural development along the Tornquist Zone, Denmark, Tectonophysics, 252 (1-4), $197-$ 220, 1995.

Mrozek, K.: Budowa geologiczna struktur wgłębnych w południowej czȩści synklinorium łódzkiego, Wyd. Geol. Warszawa, 1975.

Oberc, J.: Budowa Geologiczna Polski, Tom IV, Tektonika, cz. 2, Wyd. Geol., Warszawa, 1972.

Oszczypko, N. and Ślączka, A.: The evolution of the Miocene basin in the Polish Outer Carpathians and their foreland, Geologicky Zbornik, Geologica Carpathica, 40 (1), 23-36, 1989.

Pożaryski, W.: Tektonika elewacji radomskowskiej, Rocz. PTG, 41, 169-178, 1971.

Pożaryski, W.: Elewacja radomszczańska, in: Budowa geologiczna Polski IV, Tektonika, cz. 1, Niż Polski, Wyd. Geol., Warszawa, 322-329, 1974.

Pożaryski, W.: Waryscyjski etap platformowego rozwoju tektonicznego Europy środkowej. Przegl. Geolo. 34, 117-126, 1986.

Pożaryski, W. and Dembowski, Z.: Mapa geologiczna Polski i krajów ościennych bez utworów kenozoicznych, mezozoicznych i permskich, Warszawa, 1984.

Pożaryski, W. and Tomczyk, H.: Schemat pionowego podziału tektonicznego Polski, Biull. 236 IG, v. II, Tectonic researches in 
Poland, 5-25, 1969.

Pożaryski, W., Tomczyk, H., and Brochwicz-Lewiński, W.: Tektonika paleozoiku podpermskiego obszaru warszawskiego, Przeg. Geol., 28 (2), 73-81, 1980.

Ratschbacher, L., Frisch, W., Linzer, H. G., and Merle, O.: Lateral extrusion in the Eastern Alps, Part 2: Structural Analysis, Tectonics, 10, 2, 257-271, 1991.

Rühle, E. (red.): Mapa geologiczna Polski bez utworów kenozoicznych i kredowych 1:500 000, Warszawa, 1978.

Stuchlik, L., Szynkiewicz, A., Łańcucka-Środoniowa, M., and Zastawniak, E.: Wyniki dotychczasowych badań paleobotanicznych trzeciorzędowych węgli brunatnych złoża "Bełchatów", Acta Paleobotanica, 30 (1, 2), 259-305, 1990.

Stuchlik, L. and Szynkiewicz, A.: General geological situation and palynological investigations of the brown coal deposits, in: The $5^{\text {th }}$ European Paleobotanical and Palynological Conference - Tertiary-Quaternary (Pleistocene) floras of Bełchatów (Middle Poland) and several localities in south-western Poland, 6-11, 1998.
Trzepierczyński, J.: Struktura podłoża waryscyjskiego na północ od Górnośląskiego Zagłębia Wȩglowego, Prz. Geol., 33 (8), 1985.

Trzepierczyński, J.: Tektonika paleozoiku w strefie granicznej podłoża monokliny przedsudeckiej i śla̧sko-krakowskiej, Biul. Inst. Geol., 357, 61-98, 1987.

Wilczyński, R.: Dotychczasowe wyniki badań podstawowych serii poznańskiej w świetle geologiczno-inżynierskich problemów prowadzenia robót górniczych w KWB Bełchatów, Acta Uniw. Wratis., Pr. Geol. Miner., 26, Wrocław, 91-108, 1992.

Wysokiński, L. and Zapaśnik, T.: Poligeniczność tektonicznego rowu Bełchatowa, Technika Poszukiwań Geologicznych, 2, 2-6, 1984.

Ziegler, P. A., Cloetingh, S., and Van Wees, J. D.: Dynamics of intra-plate compressional deformation: the Alpine foreland and other examples, Tectonophysics, 252 (1-4), 7-59, 1995.

Znosko, J.: Outline of the Tectonics of Poland and the Problems of the Vistulicum and Variscicum against the Tectonics of Europe, Biul. Inst. Geol., v. 274, t.IV Z badań tektonicznych w Polsce, Warszawa, 7-38, 1974. 